\section{ECONOMICS}

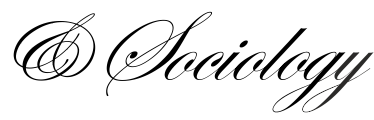

\author{
Mykhaylo Bagmet, \\ Petro Mobyla Black Sea National \\ University, \\ Mykolayiv, Ukraine, \\ E-mail: \\ mykhaylo.bagmet@gmail.com
}

Olena Liakhovets,

Petro Mobyla Black Sea National

University,

Mykolayiv, Ukraine,

E-mail:o.liakhovet_@gmail.com

Received: December, 2016

1st Revision: March, 2017

Accepted: June, 2017

DOI: $10.14254 / 2071-$

789X.2017/10-2/14

JEL Classification: I20, I28
Bagmet, M., Liakhovets, O. (2017), Towards the European Union's Education Standards: Expectations of the Ukrainians, Economics and Sociology, Vol. 10, No. 2, pp. 191-206. DOI: 10.14254/2071-789X.2017/10-2/14

\title{
TOWARDS THE EUROPEAN UNION'S EDUCATION STANDARDS: EXPECTATIONS OF THE UKRAINIANS
}

\begin{abstract}
The paper is devoted to the analysis of study results concerning the attitude of the population of Southern Ukraine to the European Union and willingness to implement the European education standards at higher education institution. The analysis of earlier studies revealed that most of the population accepts the necessity of joining the EU, its values and educational standards. But the Southern Ukraine's population has some features that distinguish it from other regions so the hypothesis was that the results would significantly differ from national polls. Using questionnaire poll and expert assessment methods to verify the hypothesis we obtained the results that showed that in the South of Ukraine a smaller share of population were less favorable to the joining the EU. The public opinion poll about the education standards, implementation of Bologna process in Ukraine and the main obstacles of it demonstrated that students and faculty were willing to implement Bologna principles but financial limitations, corruption, lack of information were still the determinants of a weak progress in this area.
\end{abstract}

Keywords: education standards, the European Union, sociological survey, Bologna process, Ukraine.

\section{Introduction}

Ukrainian education reforms oriented on Bologna system of higher education implementation are still criticized because of their imperfection, slowness and the lack of institutional strategy. But the main consumers of the reforms and education innovation are students and employers in spite of the fact that in Ukraine state interests dominate over social.

Ukrainian system of education inherited a lot of rudiments of Soviet system but during the years of independence it was affected also by its own, contradictory factors of evolution. Public education policy resisted significant wavering which, in turn, stipulated changes in the attitude to the integration to the European higher education and scientific research area: from sincere aspiration to conjunctural adjustments. As Staab (2011) denoted, the European Commission argued that future priorities ought to include sustainable development (termed "green growth") innovation and education in a new agenda rebranded the "EU 2020 strategy".

From March 2014 on, the direction of education policy of Ukraine has radically oriented to the European standards. It was facilitated by the adoption of new Law of Ukraine 
"On Higher Education", the abolishing a number of regulations which increased the excessive bureaucracy of training process.

However, institutional factors do not reveal the full potential of Bologna process in Ukraine. They include the experience of command mode of economic management, a government as a main customer of educational services, the limitation of public priorities by adaptation to the government requirements instead of making demands to the education quality. Certainly, the implementation of Bologna process and other European education standards does not guarantee the solution ща the problems with labour market, innovation development etc. because some countries of the European Union meet the same problems according to E. Dul'ová Spišáková et al. (2016) and H. Štimac and M. Leko Šimić (2012) or Smolag et al. (2015). But this will give new opportunities for economic and human capital development in Ukraine.

Today the significant place belongs to attraction of students to the Association Agreement between Ukraine and the European Union which anticipates also tourism development, youth problems solution, socio-economic, education and other social problems solution.

The detailed analysis of the results of the research is given below. We would like to emphasize that in spite of slow changes in South of Ukraine citizens' opinion concerning the European Union more than a half of citizens support closer relations of Ukraine and the EU, including in education issues.

The research goal of the paper is to reveal the attitude of educational process participants in the South of Ukraine to the perspectives of the joining the European Union and full implementation of the European higher education standards in Ukraine with use of sociological survey.

The paper is organized as follows. Section 1 is devoted to the empirical background and the studies concerning the attitude to European education standards in transformation economics held before. Section 2 introduces the results of sociological survey of public opinion of Ukrainians about the European Integration and European education standards implementation. It includes the research methodology and the analysis of survey results. Conclusions summarize the research and contain some recommendations for theory, practice, and future research on the topic.

\section{Literature review}

There are many sociological studies on Bologna process implementation held by domestic and foreign scientists.

Moiseeva and Usachov (2014), Ivanov et al. (2012) indicate that the process of education system integration to European standards is perceived by Ukrainian people ambiguously. Besides different peculiarities and differences in the European and Ukrainian systems there are some traditions that are difficult to break. This is typical for other countries seeking the EU Membership (see e.g. Glazar and Strielkowski, 2010; Bilan and Jarecki, 2012). The model of training in domestic universities does not correspond completely to the European standards. Students abroad study on a modular system which to a great extent differs from Ukrainian associated with old semester system.

On the one hand, shaped with the European principles of education Ukrainian education became creatively oriented. A student learns to use informational resources independently, to process them and to generalize that significantly differs from memorization. On the other hand, the rudiments of the old method of teaching (reproductive), unwillingness of faculty to use new pedagogical technologies, inflexibility of university system still are the obstacles in promoting the European education standards. 
Kyshenko and Nakhabich (2010) in 2008-2009 conducted the survey among the students of Kyiv National University named after T. G. Shevchenko devoted to problems of adaptation to the training process in terms of inclusion of national education system to the European education area. According to two-layer probabilistic sample 407 students were interviewed in each wave of the survey of the first, second and the third years of study. The results showed that the number of students which were proponent of Bologna system has increased during the year from $21.0 \%$ to $34.3 \%$ and that difference was statistically significant. The main factors influencing on Bologna system contentment were the technology of training and informational resources provision.

Every year the monitoring of Ukrainian education system integration to the European higher education and scientific research area based on official statistics of Ukraine and sample surveys and supported by the charity Foundation "International Foundation of Education Policy Research" (2014) took place. The authors of the monitoring define the lack of national education statistics, its incompatibility with the European statistics what forced them to do some independent evaluations and calculations of set of important quantitative indicators. The results of the monitoring demonstrate both positive and negative changes. The negative include the lack of motivation of students, faculty and universities to develop, obsoleteness of the system of values in education, a failure to fulfill obligations in the higher education area (financing, privileges etc.), inadequacy of quality of education evaluation systems to the modern requirements, bureaucratization (compare Štefko et al., 2016). Totally, monitoring generalizes the trends of higher education development in Ukraine and does not detail the impact of Bologna process.

The public opinion poll concerning the quality of higher education and the attitude to certain problems in this sphere was held by Foundation "Democratic Initiative named after Ilko Kucheriv" $(2012$, 2015). But they are mostly devoted to the current state of education in the country and its assessment by the students and less - to the results of Bologna process implementation. In 20121001 students from 51 universities of 20 cities of Ukraine in 15 regions, Kyiv, Sevastopol and Autonomous Republic of Crimea were interviewed. 93\% of interviewed know well the gist of Bologna system or have some understanding of the system. In general, respondents indicated the weak realization of education policy in the direction of Bologna process that reflected in poor knowledge of main possibilities of the reform (programs of academic mobility and exchange, obtaining the Europass Diploma Supplement, selection of the part of subjects by students' own preferences) (Bologna Process in Ukraine, 2012).

In 2015 the public opinion changed on the direction of increase in knowledge of Bologna system. It was also stipulated by the adoption a new Law of Ukraine "On Higher Education" on 1 July 2014, which provisions are implemented in stages. At the same time many students became oriented of studying abroad $-69 \%$ of interviewed, and most of all they were students of technical specialties - almost $80 \%$. The main obstacles of this perspective realization there were the resource limitation $(71 \%)$ and insufficient knowledge of foreign languages $(37.5 \%)$. Moreover, the most important problems are difficulties with Ukrainian diploma recognition in the world $(51 \%)$, a mismatch of teaching to the market requirements (41\%), corruption of the teaching staff $(39 \%)$, low level of education quality in Ukrainian universities in comparison with the European level (32\%) (Higher Education in Ukraine: public opinion of students, 2015).

In Bologna Process Implementation Report (2015) the evaluation of achievements related to Bologna process principle implementation in countries-participants were made. Unfortunately most of the indicators for Ukraine are not available that is why there are some difficulties with the objective evaluation. However, some indicators (Stage of implementation of Diploma Supplement, Implementation of national qualifications frameworks, and Access to the next cycles) demonstrate that Ukraine has the lowest rates. 


\section{A Survey of Public Opinion on the European Integration and European Education Standards Implementation in Ukraine}

\subsection{Research methodology}

Monitoring took place in 2013-16 years and covered Mykolayiv, Kherson and Odessa regions of Ukraine. The study was based on such methods:

1. Public opinion poll - for studying the public opinion on European integration processes development. Public opinion poll was used as a most informative method to measure the public views regarding the implementation some innovations in publicly important area, as in our case - education. Its results give a picture of public attitude to important questions and show the problems the public policy should be emphasized on. This method foresees use of different types of samples in order to focus on those social groups which are important for study. In comparison with other methods of gathering information the properties of this method (intelligibility, directionality, effectiveness, and reliability) provide consistency, accuracy and targeting of information that cannot be obtained in other way than by interviewing or questioning.

2. Expert assessment method - for empirical study of problems of European integration. As O. Karyy and O. Knjazevska (2009) pointed out the method is one of the components of non-quantitative objects statistics and allows aggregating the expert's thoughts, building of aggregated indexes and rankings. It can provide quick and relatively inexpensive feedback regarding the subject of the research. The method has been used for interviewing the lecturers of the tertiary education institutions. The weakness of the method is a possibility of inadequate assessment of the subject of the research what may cause the biased results.

The data gathered during the interviewing and by questionnaire was processed using such techniques as grouping, reduction, and graph analysis.

The research was intended to determine the citizens' attitude to the European Union and privileges that can be obtained by the country in terms of full membership in the EU. Next stage anticipated the interviewing of teaching staff on the European educations standards.

The study consists of several surveys:

1. A survey concerning the general attitude to joining the European Union. The number of enrolled respondents was 600 people of different ages. The survey was held with use of questionnaires. It contains 10 questions. The sample is random and representative in order to make some generalization for the whole region.

2. A survey concerning the implementation of the European education standards. The sample of respondents consists of 175 school teachers from Kherson and Mykolayiv regions; of 375 professors from universities of Kherson, Mykolayiv and Odessa region; and of 409 students from Kherson, Mykolayiv and Odessa regions. Here the quota sampling was implemented to reflect the structure of the focused groups of the research - teachers, students and professors. The detailed composition of each group of the sample is described in research results.

The sampling error does not exceed $5 \%$ with probability 0,954 .

\subsection{Research results}

South region of Ukraine can be characterized by a set of features that became the base for its choice for research. They are:

- high level of the mosaic index for the ethnic composition of the region (Greenberg 
language diversity index is 0.387 );

- the presence of significant in number inoethnic diasporas;

- compact arrangement of several ethnic groups in the territory of the region accompanied with divergence of ethnic fields of big cities;

- historical memory of the peoples unfair deportation;

- insufficient self-identification as citizens of Ukraine;

- border location of the region.

These features have stipulated such survey results.

Nine questions were asked about the attitude to the European Union (Diagrams 1-9).

Most respondents support the steady state of the Ukrainian economy and they likely won't support cardinal reforms or they will be rather painful for the society with weak adaptation at first stages of implementation. The experience of implementation of some of the reforms (raising the retirement age, increase in public utilities tariffs etc.) has argued it. At the same time perspectives of the membership in the European Union requires quick and basic reformation in many economic spheres.

1. What is the most important for the Ukrainian society?

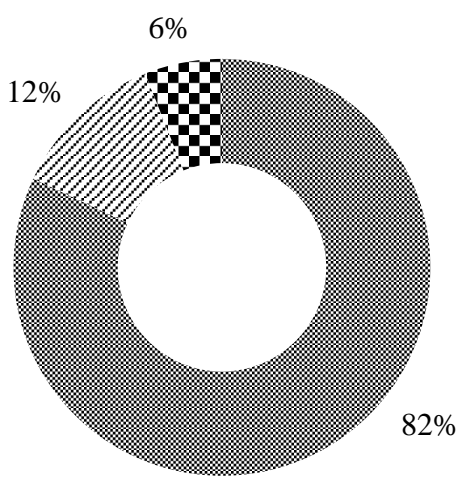

Stability

$\because$ Cardinal changes

-' Difficult to answer $82 \%$
2. How do you estimate the level of your awareness about the EU?



Diagram 2. Results about the level of awareness about the EU

Source: authors.

Diagram 1. Results of the survey about
the important factors for the Ukrainian society Source: authors.

More than $85 \%$ of surveyed have a high or medium level of awareness about the EU, so they have enough information about the necessary changes in the Ukrainian economy to start membership in the EU. The corruption is determined as the most important problem for Ukraine by $74.2 \%$ of respondents. It also hinders the socio-economic development of the country. 
3. What social problems solution you consider the most important for Ukraine?
4. What do you think if Ukraine should seek the EU membership?

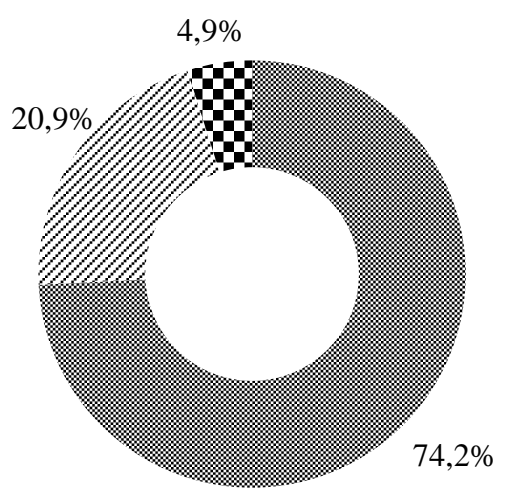

Diagram 3. Results for the most important membership of problem solutions for Ukraine Source: authors.

5. Which in your opinion could be the consequences of Ukrainian membership in the EU?

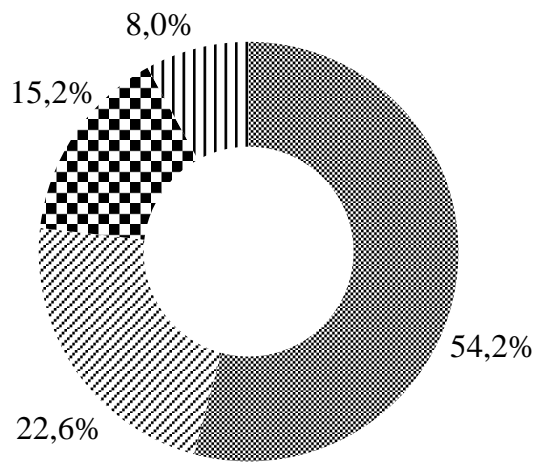

\footnotetext{
- Ukraine's credibility would increase

$\measuredangle$ The economic development would start

The relations with Russia would deteriorate II Other variants
}

Diagram 5. Results about the consequences of Ukrainian membership in the EU

Source: authors.

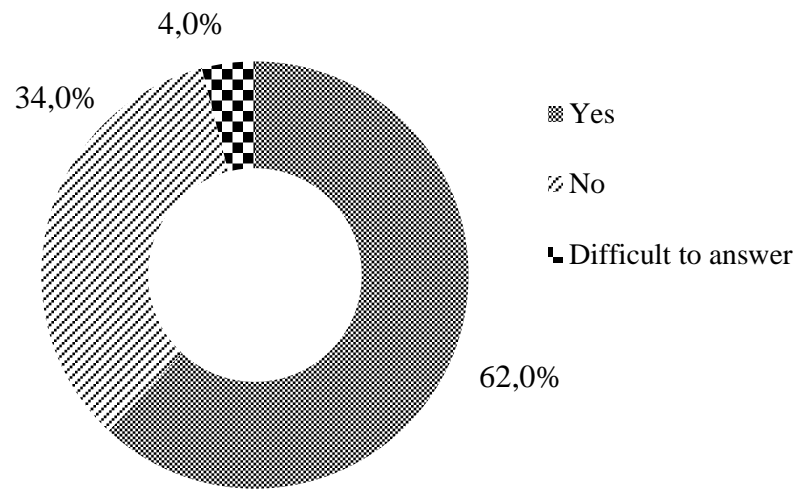

Diagram 4. Results about the Ukraine in the EU

Source: authors.

6. What in your opinion is the greatest obstacle to Ukraine on the way of integration with the EU?

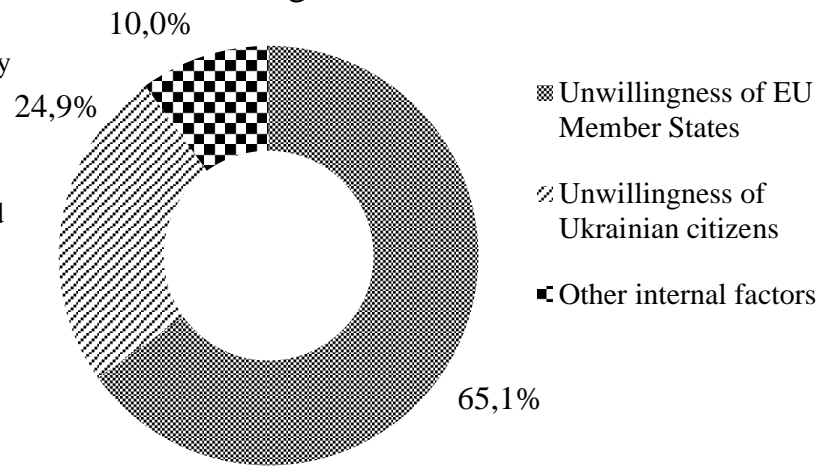

Diagram 6. Results about the obstacles to Ukraine on the way of integration with the EU

Source: authors.

The survey shows that more than $60 \%$ of interviewed think that Ukraine should seek the EU membership and this would increase Ukraine's credibility $(54.2 \%)$ and push the economic development (22.6\%). 65.1\% of respondents are sure that the basic obstacle on the way of integration with the EU is the unwillingness of EU Member States but the determinants of their willingness depends on Ukrainian government and citizens. 
7. What would be your choice if a referendum on issue of Ukraine's membership in EU would be held?
8. Did you or your relatives travel abroad during last 5 years to work or to study?

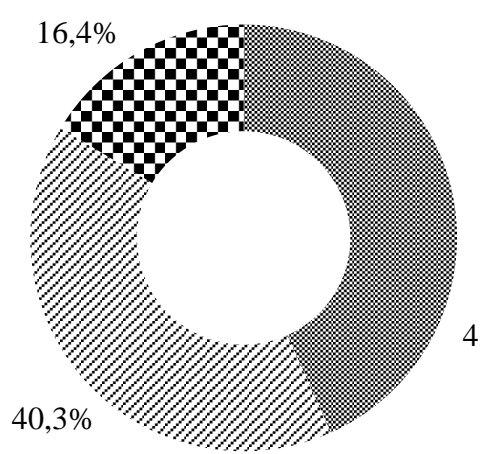

\%or

$\checkmark$ Against

Difficult to answer

$43,3 \%$
Diagram 7. Results about the choice of Ukrainians regarding membership in the EU Source: authors.



Diagram 8. Results about the implication of respondents to studying or working abroad Source: authors.

9. How do you estimate your welfare?

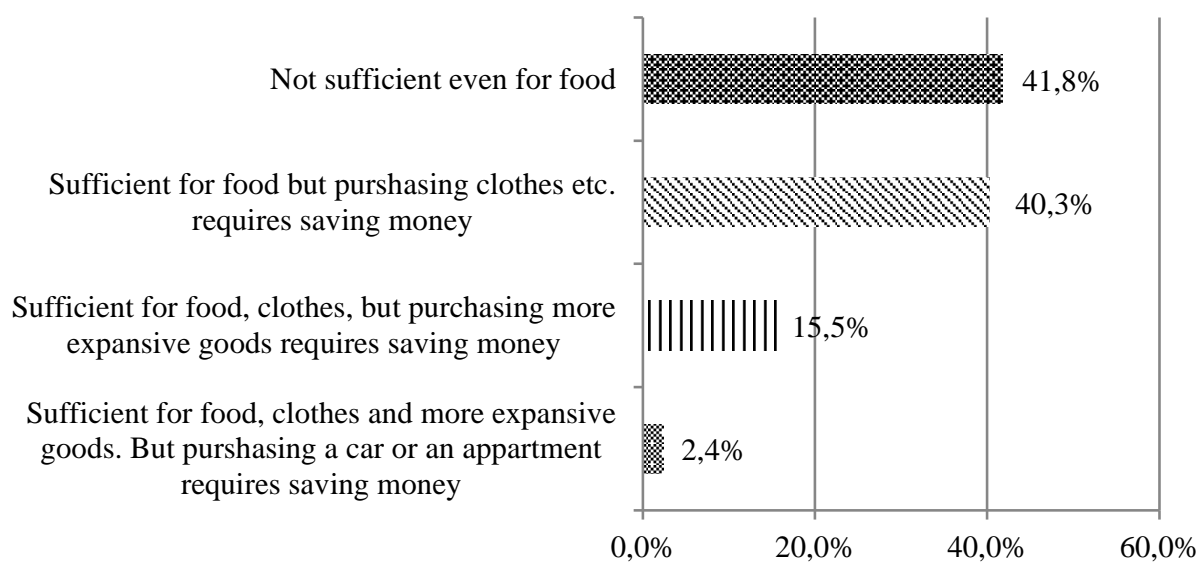

Diagram 9. Results about welfare estimations by respondents

Source: authors.

In spite of the fact that the majority of respondents in the South of the country see many benefits for Ukraine from the membership in the European Union only $43.3 \%$ of them would vote for the membership and a little less $-40.3 \%$ against. It corresponds to the national survey results obtained by Rasumkov Centre (2011), where about $45 \%$ of interviewed were ready to vote for the membership, and $34.2 \%$ against, and less than the generalized results of 2015 sociological survey held also by Rasumkov Centre (2015). It showed that $52.7 \%$ would like Ukraine to be a part of the European Union. In comparison South Ukraine showed only $33.6 \%$ positive answers. The main reason of the weak support is the lack of personal benefits or some losses that the membership may cause.

Almost $3 / 4$ of respondents confirmed that they or their relatives have travelled abroad during last 5 years to work or to study. The level of the respondents' welfare is quite low $82.1 \%$ has not sufficient income for purchasing more than food.

A certain attitude to the European Union and perspectives of the relations between Ukraine and the EU in the South of Ukraine has been already formed before the Revolution of 
Dignity. The survey of respondents concerning the benefits of membership of Ukraine in the EU has shown such results (Table 1).

Table 1. On your opinion, what benefits would Ukraine get if the country has become a fullfledged member of the EU? (in \%)

\begin{tabular}{lccc}
\hline Answer: & ages 18-29 & ages 30-54 & $\begin{array}{c}\text { ages 55 and } \\
\text { older }\end{array}$ \\
\hline Free mobility through the border & $46.1 \%$ & $35.2 \%$ & $24.3 \%$ \\
\hline $\begin{array}{l}\text { Increase in people's welfare } \\
\text { Free access to the study at the European } \\
\text { universities for the youth }\end{array}$ & $32.6 \%$ & $27.1 \%$ & $25.7 \%$ \\
\hline Improvement of goods provision & $31.8 \%$ & $24.1 \%$ & $18.3 \%$ \\
\hline $\begin{array}{l}\text { It will promote the country's progression to } \\
\text { the modern European civilization }\end{array}$ & $21.9 \%$ & $15.6 \%$ & $12.0 \%$ \\
\hline It will promote democratization & $22.9 \%$ & $16.2 \%$ & $10.3 \%$ \\
\hline $\begin{array}{l}\text { It will promote Ukrainian economy } \\
\text { development }\end{array}$ & $18.2 \%$ & $12.7 \%$ & $11.6 \%$ \\
\hline $\begin{array}{l}\text { Ukraine's credibility will increase at the } \\
\text { international level }\end{array}$ & $16.8 \%$ & $13.3 \%$ & $10.3 \%$ \\
\hline Financial aid & $15.2 \%$ & $11.2 \%$ & $8.0 \%$ \\
\hline $\begin{array}{l}\text { It will strengthen security / defensive } \\
\text { potentialities of the country }\end{array}$ & $15.2 \%$ & $9.1 \%$ & $6.1 \%$ \\
\hline Other & $7.2 \%$ & $7.6 \%$ & $7.6 \%$ \\
\hline No benefits & $0.8 \%$ & $0.7 \%$ & $0.3 \%$ \\
\hline Difficult to answer & $19.5 \%$ & $27.2 \%$ & $35.3 \%$ \\
\hline
\end{tabular}

Source: authors.

The problems of social and cultural development and specifically the tasks of modern national education system in terms of the European integration processes were widely discussed during the set of the conferences and round tables held by Petro Mohyla Black Sea National University in 2013-2016. Monitoring results the discussions were based on have testified the necessity of social, cultural, and education innovation implementation. Monitoring surveys concerns such areas:

1. The attitude of the professors of the higher education institutions to the problems of implementation of innovation.

2. Problems of updated higher education system functioning: students' view.

3. Recommendations regarding the implementation of the special training courses on this subject.

The survey held on January-March 2016 included such respondents:

- 172 teachers $(40.7 \%$ - the representatives of general secondary education institutions in Kherson and 59.3\% - in Mykolayiv). The interviewed persons are distributed by the type of education institutions in such a way: $62.2 \%$ - schoolteachers of general secondary education schools; $15.1 \%$ - specialized schools with in-depth study of specific subjects; $16.9 \%$ - lyceums, gymnasiums, collegiums; $5.8 \%$ - educational complexes;

- 375 professors (15.2\% - representatives of higher education institutions of Kherson, $18.1 \%$ - of Mykolayiv, $66.7 \%$ - of Odessa). The interviewed persons consist of $14.9 \%$ of doctors of sciences, $75.7 \%$ of candidates of sciences, $18.1 \%$ without scientific degree; 
- 409 students (14.4\% study at higher education institutions of Kherson, $19.3 \%$ of Mykolayiv, $66.3 \%$ of Odessa; $48.9 \%$ of males and $51.1 \%$ females; the number of first year students was $47.2 \%$, students of graduation year (specialists, masters) $-52.8 \%$ ).

The key competences adopted by the European Council which should be possessed by the European youth are the abilities to learn, to seek, to think, to cooperate, to tackle the problem, to adapt. The opinion of the respondents mentioned above concerning these and other competences was studied in the survey held in the South of Ukraine (Table 2).

Table 2. The formation of what important skills and abilities of students do you prefer in your teaching practice?

\begin{tabular}{lc}
\hline Answer: & $\%$ \\
\hline To solve research and application problems & 0.8 \\
\hline To study independently, to find necessary information & 16.6 \\
\hline To make correlations between own needs and possibilities & 4.3 \\
\hline To use obtained knowledge in practice & 18.9 \\
\hline To be organized and responsible & 9.1 \\
\hline To take care of health & 7.7 \\
\hline To find understanding and to cooperate with others & 9.7 \\
\hline To orient quickly in different situations & 10.8 \\
\hline To think critically, to formulate independent judgments and to make decisions & 22.0 \\
\hline Your variant & 0 \\
\hline Difficult to answer & 0.3 \\
\hline
\end{tabular}

Source: authors.

The analysis of the ways of getting information about the innovations in the secondary education system in the EU is presented in the Table 3.

Table 3. What sources of reliable information on the innovations in the secondary education system in the EU do you use?

\begin{tabular}{lc}
\hline Answer: & $\%$ \\
\hline Professional trainings, seminars, master classes & 14.8 \\
\hline Round tables, conferences & 7.3 \\
\hline Webinars, communication in professional Internet-forums, social networks & 7.7 \\
\hline Overseas internship & 4.1 \\
\hline Reserve school, professional development courses & 8.1 \\
\hline $\begin{array}{l}\text { Cooperation with National Academy of Science of Ukraine, Ministry of Education } \\
\text { and Science of Ukraine }\end{array}$ & 1.9 \\
\hline Printed media & 4.4 \\
\hline Scientific and methodical literature & 11.4 \\
\hline Official documents, legislative acts & 11.4 \\
\hline Administration of educational institutions & 11.6 \\
\hline Internet resources & 11.4 \\
\hline $\begin{array}{l}\text { Department of Education and Science Administration of State Regional } \\
\text { Administration, Administrations of Education of Local and Regional Governments }\end{array}$ & 5.2 \\
\hline Your variant & 0.6 \\
\hline
\end{tabular}

Source: authors. 
The results of the survey of the teaching staff showed the lack of efficiency of the information and education function of regional structural divisions of Ministry of Education and Science of Ukraine. Only one third of the interviewed (34.9\%) marked that the measures with the purpose of familiarization with the content and stages of the European education standards are held in their town, rayon or region. Administrations of educational institutions and Administrations of Education and Science are mostly the initiators of such measures. Concerning the content of such measures no one of the respondents could point out in details the directions of discussions what indicated that they answered formally. The monitoring results confirmed it (Table 4).

Table 4. Survey results about the measures which are related to implementation of the European education standards

\begin{tabular}{lc}
\hline $\begin{array}{l}\text { Are there any measures held in your town (rayon, region) related to familiarization } \\
\text { with the content and stages of the European education standards implementation? }\end{array}$ & $\%$ \\
\hline Yes & 34.9 \\
\hline No & 12.2 \\
\hline Difficult to answer & 52.9 \\
\hline $\begin{array}{l}\text { If you answered "yes" the previous question then indicate who was the initiator of such } \\
\text { measures? }\end{array}$ & $\%$ \\
\hline National Academy of Science of Ukraine, Ministry of Education and Science of Ukraine & 1.4 \\
\hline Department of Education and Science Administration of State Regional Administration & 16.7 \\
\hline Administrations of Education of Local and Regional Governments & 27.8 \\
\hline Administration of higher education institution & 31.9 \\
\hline Institute of postgraduate education & 18.1 \\
\hline Higher education institutions of the town & 4.2 \\
\hline Your variant & 0 \\
\hline
\end{tabular}

Source: authors.

The answers on a question about the reliable sources of information about the European education standards showed such results (Table 5).

Table 5. What sources of reliable information on the European education standards do you use?

\begin{tabular}{lc}
\hline Answer: & $\%$ \\
\hline Professional trainings, seminars, master classes & 7.8 \\
\hline Round tables, conferences & 12.4 \\
\hline Webinars, communication in professional Internet-forums, social networks & 7.4 \\
\hline Overseas internship & 9.2 \\
\hline Professional development courses & 2.0 \\
\hline $\begin{array}{l}\text { Cooperation with National Academy of Science of Ukraine, Ministry of Education } \\
\text { and Science of Ukraine }\end{array}$ & 7.0 \\
\hline Mass media & 9.5 \\
\hline Scientific and methodical literature & 11.8 \\
\hline Official documents, legislative acts & 13.2 \\
\hline Administration of higher education institutions & 5.8 \\
\hline Internet resources & 12.7 \\
\hline Your variant & 1.0 \\
\hline
\end{tabular}

Source: authors. 
The competent professors who have both basic theoretical knowledge and a certain international practical experience are the inalienable element of establishment and functioning of successful European authoritative institution of higher education.

The answers obtained during the survey showed the aspiration to use different forms of international cooperation (Table 6).

Table 6. What types of international cooperation do you consider effective for the education improvement at your higher education institutions?

\begin{tabular}{lc}
\hline Answer: & $\%$ \\
\hline Internship (of professors, students, administrative personnel) in foreign universities & 32.6 \\
\hline Joint (with foreign partners) research projects, publications & 19.3 \\
\hline Joint (with foreign partners) training programs & 17.9 \\
\hline Invitation of lecturers for teaching abroad & 10.9 \\
\hline Participation of professors, students, managerial personnel in conferences, seminars & 19.0 \\
\hline Your variant & 0.2 \\
\hline Difficult to answer & 0.2 \\
\hline
\end{tabular}

Source: authors' calculations.

Also the questionnaire was accompanied with a question related to trips abroad with the purpose of familiarization with the experience of the European universities (Table 7).

Table 7. Have you ever undertaken a business trip with the purpose of familiarization with the experience of the European universities? (in \%)

\begin{tabular}{lccc}
\hline Answer: & $\begin{array}{c}\text { Doctors of } \\
\text { sciences }\end{array}$ & $\begin{array}{c}\text { Candidates of } \\
\text { sciences }\end{array}$ & $\begin{array}{c}\text { Without scientific } \\
\text { degree }\end{array}$ \\
\hline Yes, many times & 7.1 & 0.7 & 0 \\
\hline Yes, several times & 10.7 & 10.7 & 2.9 \\
\hline Yes, once & 12.5 & 6.8 & 8.6 \\
\hline No, not once & 69.6 & 81.9 & 88.6 \\
\hline
\end{tabular}

Source: authors.

Professors, speaking about the necessity of international cooperation, indicate the expedience of education improvement at domestic universities. But the main attention should be paid to internship both professors and students. The basic obstacle for the efficient international cooperation is the resources limitation (deficit of financial resources, information etc.) and insufficient level of willingness of university personnel.

The organizers of monitoring formulated questions for faculty concerning the determinants of successful implementation of European education standards (Table 8).

Table 8. What do you need to consider yourself a full European?

\begin{tabular}{|c|c|}
\hline Answer: & $\%$ \\
\hline 1 & 2 \\
\hline A certain level of welfare & 25.9 \\
\hline To respect democracy values and human rights & 6.2 \\
\hline To have a possibility to go to Europe without visa & 8.0 \\
\hline To feel yourself protected by a law & 22.9 \\
\hline
\end{tabular}




\begin{tabular}{lc}
\hline \multicolumn{1}{c}{1} & 2 \\
\hline To have a possibility to elect the government on democratic elections & 9.4 \\
\hline To feel yourself a free personality & 5.7 \\
\hline To speak foreign languages & 15.1 \\
\hline To know and to respect European culture & 0.8 \\
\hline Need nothing because Ukrainians are Europeans & 3.8 \\
\hline Consider it is not necessary for Ukrainians to feel like Europeans & 1.4 \\
\hline Your variant & 0.3 \\
\hline Difficult to answer & 0.4 \\
\hline
\end{tabular}

Source: authors.

Students were asked to answer questions concerning the quality of higher education services, motivational aspirations about future employment, problems with corruption at higher education institutions and student's plagiarism. Results of the research about the obtaining of reliable information are in Table 9.

Table 9. What sources of reliable information on the European education standards do you use?

\begin{tabular}{lc}
\hline Answer: & $\%$ \\
\hline Administrative personnel of higher education institution & 17.1 \\
\hline Professional trainings, seminars, master classes & 12.9 \\
\hline Scientific and methodical literature & 12.4 \\
\hline Overseas internship & 12.2 \\
\hline Professional development courses & 12.1 \\
\hline $\begin{array}{l}\text { Cooperation with National Academy of Science of Ukraine, Ministry of Education } \\
\text { and Science of Ukraine }\end{array}$ & 8.1 \\
\hline Round tables, conferences & 6.8 \\
\hline Webinars, communication in professional Internet-forums, social networks & 6.2 \\
\hline Official documents, legislative acts & 5.9 \\
\hline Mass media & 4.6 \\
\hline Internet resources & 0.3 \\
\hline Your variant & 1.4 \\
\hline
\end{tabular}

Source: authors.

A new version of the Law of Ukraine "On Higher Education" contains a set of innovations related to students. Particularly, they concerns the decreasing of academic load on students, selection of not less than $25 \%$ of courses, free specialty choice for bachelors in case of admission to Master programs, new mechanism of electronic entrance to the university, amplification of anti-plagiarism norms and responsibility for its violation, increasing role of students governance etc.

In turn, for most students the main features of the European education standards implementation in domestic high school are: the possibility to obtain Europass Diploma Supplement $(20.6 \%)$, the assessment of knowledge quality by the ECTS (14.9\%), creditmodular system of education (14.2\%), the possibility after the bachelor degree to enter the master program in another university in Ukraine or abroad (12.4\%).

The analysis of students' answers concerning their competency about the events hosted in the higher education institutions, their initiators and problems discussed showed the inefficiency of information divisions of Department of Education, administration of higher 
education institutions. Only $34.7 \%$ of interviewed indicate that such events take place, most of the students $(47.9 \%)$ have some difficulties with answers on this question.

An international cooperation with leading European universities is the integral part of the successful activity of the domestic universities. Students have determined the most effective types of international cooperation which were: an internship both of professors, administrative personnel and students in foreign universities $(34.6 \%)$, the necessity of foreign professors invitation to do lecturing $(20.5 \%)$, joint education project realization with foreign partners $(19.3 \%)$. In this situation their opinion is similar to professors' judgments (Table 10).

Table 10. What types of international cooperation do you consider effective for the education improvement at your higher education institutions?

\begin{tabular}{lc}
\hline Answer: & $\%$ \\
\hline Internship (of professors, students, administrative personnel) in foreign universities & 34.5 \\
\hline Joint (with foreign partners) research projects, publications & 7.2 \\
\hline Joint (with foreign partners) training programs & 19.3 \\
\hline Invitation of lecturers for teaching abroad & 20.5 \\
\hline Participation of professors, students, managerial personnel in conferences, seminars & 14.5 \\
\hline Your variant & 0.2 \\
\hline Difficult to answer & 3.8 \\
\hline
\end{tabular}

Source: authors.

The main obstacles on the way of study continuation abroad for the students are: resources limitation (deficit of financial resources, information etc.) (34.3\%) and insufficient level of knowledge of foreign languages (23.2\%). Most of the interviewed students confirmed their intention to participate in international projects, conferences and competitions $(64.7 \%)$ in spite of a certain self-doubt (Table 11).

Table 11. Do you plan to participate in international projects, conferences, competitions?

\begin{tabular}{lc}
\hline Answer: & $\%$ \\
\hline Yes, with pleasure, I have all opportunities & 17.8 \\
\hline Yes, but I'm not sure to have opportunities & 46.9 \\
\hline No, I have opportunities but don't have a desire & 8.1 \\
\hline No, I have neither opportunities nor a desire & 19.8 \\
\hline I've already had positive experience & 7.3 \\
\hline I've already had negative experience & 0 \\
\hline
\end{tabular}

Source: authors.

Unfortunately the number of those who have positive experience in such projects is a little more than $7 \%$ of total number of interviewed. So there is a potential, and we need to mobilize it. Students and faculty play a great role in this process, because they create a system of motivation to successful learning.

The adaptation to the European social and cultural values and norms depends on willingness of the participants of the training process to accept innovations in the tertiary education system (Androniceanu, Ohanyan, 2016). Students are positively motivated to accept changes but there are some reasons why they cannot feel themselves part of the European community. On students' opinion they are financial limitation and a low level of welfare $(24.5 \%)$, problems with visa application (19.1\%), lack of knowledge of foreign 
languages $(15.3 \%)$, the vulnerability of the law (14.5\%).

The level of everyday culture of the students as one of the determinants of the European values implementation estimated by faculty $(50.1 \%)$ is medium, $11.2 \%$ - higher than medium, and $10.7 \%$ - sufficient. The quarter of respondents $(26.4 \%)$ emphasizes that the level of everyday culture is quite low. To a certain extent the everyday students' behavior is regulated by the Ethical Code - the official document which is present in every university. Only one third $(28.1 \%)$ of the respondents knows about it and follows its main principles. Others don't know about such document at all or don't follow it.

Among negative behavior patterns of students respondents pointed out the use of profanity (89.4\%), smoking (61.5\%), untidiness, the prudent use of training instruments (54.5\%), drinking alcohol (51.9\%). In turn most of the students have such character traits as initiative, honesty, and consciousness, adherence of dress code, patriotism, and respect for others. Students condemn negative behavior, immorality amongst their coevals (19.1\%), but only $10.5 \%$ of them actively try to prevent such behavior.

To increase the efficiency of the European education standards implementation in Ukraine students proposed such high-priority measures: the establishment of cooperation with leading universities of Europe (19.2\%), raising the level of salary of the faculty (16.6\%), practical orientation of training $(16.6 \%)$, fight with corruption $(16.4 \%)$, students initiative support concerning their participation in research activities $(11.1 \%)$.

\section{Conclusions}

The paper raises the problem of implementation of modern reforms in education in Ukraine. The adoption of such institutional changes requires the awareness and cultivation of European values. That is why we concentrated our attention on the study both the attitude to the integration of Ukraine with the European Union and to the European educational standards implementation. According to the existing resource limitations the chosen region is the South of Ukraine including three oblasts - Mykolayiv, Kherson and Odessa. It has some specific features that increase the advertence to the population and its opinion. To reveal the views of some social groups on the mentioned problems the methods of public opinion poll (interviewing and questionnaire) and expert's thought evaluation were used as the tools that give the most representative results regarding to the purpose of the sociological study.

The analysis of the last empirical studies and other monitoring researches allow making such conclusions.

Most of the interviewed in the South of Ukraine have positive attitude to the European Union and the directions of Ukrainian integration policy. These outcomes meet national poll results obtained by other organizations.

In implementation of the Association Agreement between the European Union and Ukraine issues of youth, education and culture there are some positive changes but they are quite slow and even contradictory. But the significant change is that there has been a transit from the theorization stage to practical actions, real innovation implementation in the education system - new innovation and technological stage of education reform.

In domestic education system that has been existing for many decades and professing knowledge and educational paradigm, new organizations have emerged - gymnasiums, lyceums, colleges, higher education institutions of private ownership, institutions of postgraduate and additional education etc., which practice new models, teaching technologies and training. Presently, we should move from the experimentation in seeking new forms of education, generation new education technologies, instruments and methods of education management at the level of a certain educational institution, regional and strategic (state) level to current regulations of innovation implementation in education system of Ukraine. 
Conducting empirical research among the participants of training process gives a possibility of elaboration practical recommendations to facilitate the process of national education system reformation considering regional peculiarities, social and cultural traditions, features of socio-economic situations in the country.

The key competencies immanent to young Europeans are skills to study, to seek, to think, to cooperate, to tackle the problem and to adapt. Especially it is important to pay attention on competencies related to informatization of society growth, mastering new technologies, operating the ways of critical judgments in attitude to information, ability to life-long learning. So, it is reasonable to direct actions of all participants of training and educational process on formation these competencies paying much attention to learning and appropriate use of information and communication technologies in training process and while self-education.

As a majority of interviewed during empirical researches expresses the interest in learning of best practices concerning innovation implementation in professional area, it is worth to establish cooperation and organize the internship of faculty and students in the best higher education institutions both in Ukraine and abroad.

Interviewed professors, researchers and students recognize the necessity of foreign languages knowledge improvement. It requires implementation of new methods of teaching foreign languages at the school and university levels.

One of the most progressive directions is the promotion of life-long self-education pupils, students and teaching faculty, expansion of creativity, educational interests.

Certainly, the conducted research concerns only the intermediate results of the state of public opinion in Ukrainian society regarding the implementation of the European education standards and the integration with the European Union. Furthermore, there is a significant regional unevenness, which circumscribes the research results in South Ukraine. What should be done is the periodic monitoring of the society's mood and attitude to the policy measures in education area. We consider the public opinion surveys and experts assessment methods the most appropriate and reliable instruments to obtain the information for statistical analysis. The interviewed groups and the sample should be expanded. Besides teachers, professors and students the officials of the local government have to be included to the survey. Tracking the basic trends will give a tool to the national and local governments to change their education policy to obtain better outcomes of the reforms.

\section{Acknowledgments}

The survey was supported by the Ministry of Education and Science of Ukraine and performed the results of the project "The Scientific Research of the European Social, Cultural and Educational Standards Implementation (on the Example of the Southern Region of Ukraine)" (registration number 0115U000315).

\section{References}

Androniceanu, A., Ohanyan, G.(2016). Comparative approach on education and healthcare in Romania and Bulgaria as beneficiaries of the IMF financial assistance, Administratie si Management Public, 26, 25-48.

Bilan, Y., \& Jarecki, W. (2012). Changes in the educational level of employees in Poland and Ukraine: 2000-2009. Actual Problems of Economics, 130, 331-341.

Bolonga Process in Ukraine (2012), http://dif.org.ua/ua/publications/pressrelizy/hklhttukduk.htm (referred on 26/05/2016). 
Dul'ová Spišáková, E., Gontkovičová, B., Hajduová, Z. (2016). Education from the Perspective of the Europe 2020 Strategy: the Case of Southern Countries of the European Union. Economics and Sociology, 9(2), 266-278.

Glazar, O., \& Strielkowski, W. (2010). Turkey and the European Union: possible incidence of the EU accession on migration flows. Prague Economic Papers, 19(3), 218-235. doi: https://doi.org/10.18267/j.pep.373.

Higher Education in Ukraine: public opinion of students (Vyscha osvita $v$ Ukrajini: gromadska dumka studentiv) (2015), http://dif.org.ua/ua/publications/press-relizy/vishaosvita-v-ukraini-gromadska-dumka-studentiv-.htm (referred on 30/04/2016).

Ivanov, S., Gutkevych, S., \& Dichkovskiy, S. (2012). An input of european educational standards at higher school of Ukraine-modernisation of educational system. Journal of International Studies, 5(2), 66-71.

Karyy, O., Knjazevska, O. (2009). Tasks Prioritization of Strategic Planning of Cities Development: Experts' Approach. Economics \& Sociology, 2(1), 58-66.

Kyshenko, G. I., Nakhabich, M. A. (2010). Dynamics of Junior Courses Students Adaptation to Training in Terms of Joining of Higher Education of Ukraine to the European Education Area (results of sociological research) (Dynamika adaptaciji studentiv molodshyh kursiv do navchannia $\mathrm{v}$ umovah pryednannia vyschoji osvity Ukrajiny do evropeys'kogo osvitniogo prostoru (za rezul'tatamy sociologichnogo doslidzhennia). Aktual'ni problemy sociologiji, psykhologiji, pedagogiky: Zbirnyk naukovyh prac', 11, 156-163.

Moiseeva, F. A., Usachov, V. A. (2014). The European Integration of Higher Education of Ukraine in Terms of Bologna Process (Evropeyska integracija vyschoji osvity Ukrajiny v konteksti Bolonskogo procesu), Nauka. Religija. Suspil'stvo, 1, 36-40.

Monitoring of Integration of Ukrainian System of Higher Education to the European Area of Higher Education and Scientific Research: Monitoring Research: Analytical report (Monitoring integraciji ukrajinskoji systemy vyschoji osvity $v$ Evropeysky prostir vyschoji osvity ta naukovogo doslidzhennia: monitoringove doslidzhennia: analitychny zvit) (2014), ed. by T. V. Finikov, O. I.Sharova, Kyiv: Takson.

One Third of Ukrainians does not want to enter the EU: Rasumkov Centre Research (Tretyna ukrajinciv ne hochut' do ES: doslidzhennia Centru razumkova) (2011), http://tyzhden.ua/News/37604 (referred on 10/06/2016).

Public Opinion on the European Standards Implementation in the Southern Region of Ukraine (Gromadska dumka pro vprovadzhennia evropeyskyh standartiv u pivdennomu regioni Ukrainy) (2013). Mykolayiv: Poligrafichne pidpryemstvo SPD Rumianceva G.V.

Staab, A. (2011). The European Union Explained: Institutions, Actors, Global Impact, $2^{\text {nd }}$ ed., Bloomington: Indiana University Press.

Štefko, R., Fedorko, R., Bačík, R. (2016). Website content quality in terms of perceived image of higher education institution. Polish Journal of Management Studies, 13(2), 153-163.

Štimac, H., Šimić, M. L. (2012). Competitiveness in Higher Education: a Need for Marketing Orientation and Service Quality. Economics \& Sociology, 5(2), 23-34.

The European Higher Education Area in 2015: Bologna Process Implementation Report (2015). European Commission/EACEA/Eurydice, Luxembourg: Publications Office of the European Union.

What do you think is it necessary for Ukraine to join the European Union? (Jak vy vvazhaete, chy potribno Ukrayini vstupaty do Evropeyskogo Sojuzu) (2015), http://www.razumkov.org.ua (referred on 15/05/2016). 